\title{
GAMBARAN PENGETAHUAN MASYARAKAT DALAM PENGOBATAN SENDIRI (SWAMEDIKASI) UNTUK OBAT ANALGESIK
}

\author{
Chusun $^{1}$, Nanda Sinta Lestari ${ }^{2}$ \\ ${ }^{1,2}$ Akademi Farmasi Bhumi Husada \\ Email korespondensi: chusun666@gmail.com
}

\begin{abstract}
ABSTRAK
Swamedikasi merupakan alternatif yang diambil masyarakat untuk meningkatkan keterjangkauan pengobatan. Penelitian ini bertujuan untuk mengetahui gambaran Pengetahuan Masyarakat dalam Pengobatan Sendiri (Swamedikasi) untuk Analgesik di Kelurahan Sukmajaya, Kota Depok. Penelitian ini menggunakan metode deskriptif kuantitatif. Sampel yang diambil sebanyak 250 responden yang berasal dari RW 09 dan RW 10. Sampel diambil secara random, data yang didapat dianalisis univariat dan bivariat dengan SPSS 20. Hasil penelitian menunjukan dari 250 responden, (90\%) melakukan swamedikasi dengan obat analgesik, pengetahuan masyarakat tentang swamedikasi tinggi (72\%) demikian juga pengetahuan analgesik (58.8\%). Terdapat hubungan signifikan antara pendidikan dengan pengobatan sendiri yaitu responden yang memiliki pendidikan rendah mempunyai peluang 0,321 kali melakukan swamedikasi demikian juga pengetahuan swamedikasi dengan pengobatan sendiri yaitu responden yang memiliki pengetahuan swamedikasi yang tinggi mempunyai peluang 3,193 kali melakukan swamedikasi. Alasan responden melakukan swamedikasi karena penyakit dianggap ringan $(52.4 \%)$. Sumber informasi obat paling banyak didapat dari media elektronik (88\%). Obat analgesik yang banyak digunakan yaitu parasetamol (63.6\%).
\end{abstract}

Kata kunci: Swamedikasi, Analgesik, Gambaran pengetahuan 


\title{
DESCRIPTION OF INSIDE COMMUNITY KNOWLEDGE SELF- TREATMENT (SWAMEDICATION) FOR ANALGESIC DRUGS
}

\begin{abstract}
Self-medication is an alternative that is taken by the community to increase the affordability of treatment. This study aims to determine the description of Community Knowledge in Self-medication (Self-medication) for analgesics in Sukmajaya Village Depok City. This research uses descriptive quantitative method. Samples were taken as many as 250 respondents from $R W 09$ and $R W$ 10. Samples were taken randomly, the data obtained were analyzed univariate and bivariate with SPSS 20. The results showed that from 250 respondents, (90\%) conducted self-medication with analgesic drugs, public knowledge. about high self-medication (72\%) as well as knowledge of analgesics (58.8\%). There is a significant relationship between education and self-medication, namely respondents who have low education have a chance of doing self-medication as well as knowledge of self-medication, namely respondents who have high selfmedication knowledge have a chance of 3,193 times to do self-medication. The reason respondents did self-medication was because the disease was considered mild (52.4\%). Source of drug information mostly comes from electronic media (88\%). The analgesic drug that is widely used is paracetamol (63.6\%).
\end{abstract}

Keywords: self-medication, analgesic, Community knowledge

\section{PENDAHULUAN}

Berbagai upaya telah dilakukan untuk meningkatkan kesadaran masyarakat dalam berperilaku hidup sehat dan bersih, dan pemerataan pelayanan kesehatan, namun ternyata kesehatan tetap menjadi masalah di Indonesia. Salah satu alasannya karena kemajuan teknologi dan perubahan pola hidup masyarakat yang cenderung kurang memperhatikan kesehatan. Hal ini menyebabkan berkembangnya penyakit yang mendorong masyarakat untuk mencari alternatif pengobatan yang efektif secara terapi tetapi juga efisien dalam hal biaya. Berkenaan dengan hal tersebut pengobatan sendiri menjadi alternatif yang diambil oleh masyarakat (Depkes RI, 2000).

Upaya masyarakat untuk mengobati dirinya sendiri dikenal dengan istilah self medication atau swamedikasi. Swamedikasi biasanya dilakukan untuk mengatasi keluhankeluhan dan penyakit ringan yang banyak dialami masyarakat, seperti demam, nyeri, pusing, batuk, influenza, sakit maag, kecacingan, diare, penyakit kulit dan lain-lain. Swamedikasi menjadi alternatif yang diambil masyarakat untuk meningkatkan 
keterjangkauan pengobatan (Depkes RI, 2000, Djunarko, I., dan Hendrawati, 2011)

Pada pelaksanaanya swamedikasi dapat menjadi sumber terjadinya kesalahan pengobatan (medication error) karena keterbatasan pengetahuan masyarakat akan obat dan penggunaannya. $^{2}$ Self medication menjadi alternatif yang diambil masyarakat untuk meningkatkan keterjangkauan pengobatan. Self medication juga merupakan salah satu upaya untuk mencapai kesehatan bagi semua yang memungkinkan masyarakat dapat hidup produktif secara sosial dan ekonomi (Supardi dan Notosiswoyo, 2006, Hermawati, 2011)

Penelitian yang dilakukan oleh Asmarani (tahun 2014) terhadap gambaran pengetahuan dan kerasionalan penggunaan obat bebas dan bebas terbatas menunjukan sebanyak $54,1 \%$ responden menggunakan obat secara tidak rasional, yang dilakukan terhadap masyarakat di RW 015 Kecamatan Pancoran Mas Depok.

Banyaknya masyarakat di Kelurahan Sukmajaya yang melakukan swamedikasi terhadap penyakit yang sering diderita serta relatif ringan termasuk penggunaan obat analgesik, Penelitian ini bertujuan untuk mengetahui gambaran mengenai pengobatan sendiri (swamedikasi) terhadap obat analgesik pada masyarakat

\section{METODE PENELITIAN}

Penelitian ini bersifat non eksperimental dengan teknik pengambilan data secara prospektif. Alat yang digunakan untuk memperoleh data adalah kuesioner. tipe pertanyaan yang digunakan bersifat pertanyaan tertutup (close-ended) dengan variasi multiple choice. Penelitian ini dilakukan di lingkungan masyarakat RW 09 dan RW 10 Kelurahan Sukmajaya, Kecamatan Sukmajaya, Depok.

\section{Sampling dan Teknik Sampling}

Pada penelitian ini yang dimaksud dengan populasi adalah masyarakat RW 09 dan RW 10 Kelurahan Sukmajaya Depok. Sampel pada penelitian ini adalah diambil secara random sebanyak kurang lebih 20\% dari jumlah keluarga yang ada di RW 09 dan RW 10 Kelurahan Sukmajaya yaitu kurang lebih sebanyak 250 responden.

\section{Prosedur kerja}

a. Persiapan, meliputi: perizinan, menentukan jumlah sampel yang digunakan, dan menyusun daftar pertanyaan.

b. Pengumpulan data, meliputi : membagikan lembar kuesioner kepada responden dan mengumpulkan lembar kuesioner yang telah diisi oleh responden

c. Analisis data

d. Pembahasan dan membuat kesimpulan

Pengambilan kesimpulan didasarkan pada rumusan masalah, pembahasan dan disesuaikan dengan tujuan penelitian. Saran diberikan kepada pihak yang 
berhubungan dengan penelitian ini.

\section{Analisis Data}

Analisis data yang digunakan adalah analisis deksriptif yaitu penelitian yang dilakukan dengan tujuan utama membuat gambaran tentang suatu keadaan secara objektif. data yang dikumpulkan adalah data kuantitatif, yaitu berupa data prosentase masingmasing responden dalam menjawab seluruh pertanyaan.

\section{HASIL DAN PEMBAHASAN}

Penelitian ini dilakukan di Kelurahan Sukmajaya yang merupakan salah satu kelurahan dari Kecamatan Sukmajaya.

\section{A. Demografi responden}

Dari hasil penelitian didapat distribusi frekuensi responden yang melakukan pengobatan sendiri, dapat dilihat pada tabel 1

Tabel 1. Distribusi Responden terhadap Pengobatan sendiri (swamedikasi) pada Obat Analgesik di RW 09 dan RW 10 Kelurahan Sukamajaya Depok

\begin{tabular}{clcc}
\hline No & Pengobatan sendiri & Jumlah & $\%$ \\
\hline 1 & Ya & 225 & 90 \\
2 & Tidak & 25 & 10 \\
\hline & Jumlah & 250 & 100 \\
\hline
\end{tabular}

Dari tabel 1 diatas dapat diketahui bahwa sebanyak 25 responden (10\%) belum pernah melakukan swamedikasi terhadap obat nyeri, dan sebanyak 225 responden (90\%) melakukan swamedikasi terhadap rasa nyeri dengan menggunakan analgesik.

\section{Gambaran umur responden}

Tabel 2. Distribusi Responden berdasarkan Umur di RW 09 dan RW 10 Kelurahan Sukmajaya Depok

\begin{tabular}{crcc}
\hline No & \multicolumn{1}{c}{ Kategori Umur } & Jumlah & $\%$ \\
\hline 1 & $<30$ tahun & 99 & 39.6 \\
2 & $\geq 30$ tahun & 151 & 60.4 \\
\hline \multicolumn{2}{l}{ Jumlah } & 250 & 100 \\
\hline
\end{tabular}

Dari tabel 2 diatas dapat diketahui bahwa sebanyak 99 responden $(39.6 \%)$ berusia <30 tahun, dan sebanyak 151 responden $(60.4 \%)$ berusia $\geq 30$ tahun. Dari hasil penelitian terhadap karakteristik responden yang didapat bahwa responden dengan umur $\geq 30$ tahun lebih menunjukan sikap antusias dan terbuka. Selain itu mereka sudah banyak melakukan pengobatan sendiri 
untuk menghilangkan nyeri dengan menggunakan obat analgesik yaitu sebanyak 151 responden $(60.4 \%)$.

\section{Gambaran responden berdasarkan jenis kelamin}

Tabel 3. Distribusi Responden berdasarkan Jenis Kelamin di RW 09 dan RW 10 Kelurahan Sukmajaya Depok

\begin{tabular}{clcc}
\hline No. & \multicolumn{1}{c}{ Jenis Kelamin } & Jumlah & $\%$ \\
\hline 1 & Laki-laki & 114 & 45.6 \\
2 & Perempuan & 136 & 54.4 \\
\hline & Jumlah & 250 & 100 \\
\hline
\end{tabular}

Dari tabel 3 diatas dapat terlihat dari jumlah responden laki laki diketahui bahwa sebanyak 114 yaitu sebanyak 114 orang (45.6\%), dan responden (45.6\%) adalah laki-laki, responden perempuan yaitu sebanyak dan sebanyak 136 responden (54.4\%) adalah perempuan. Berdasarkan jenis kelamin tidak ada perbedaan yang signifikan dalam hal jumlah responden yang melakukan swamedikasi. Hal ini

136 orang $(54.4 \%)$.

\section{Gambaran responden berdasarkan pendidikan}

Tabel 4. Distribusi Responden berdasarkan tingkat Pendidikan di RW 09 dan RW 10 Kelurahan Sukmajaya Depok

\begin{tabular}{clcc}
\hline No. & Tingkat Pendidikan & Jumlah & $\%$ \\
\hline 1 & Rendah & 179 & 71.6 \\
2 & Tinggi & 71 & 28.4 \\
\hline & Jumlah & 250 & 100 \\
\hline
\end{tabular}

Dari tabel 4 dapat diketahui bahwa 71 responden $) 28,4 \%$ ) berpendidikan

tinggi (Perguruan Tinggi), dan sebanyak 179 responden $(71.6 \%)$ berpendidikan rendah SMA/SMP/SD). Tingkat pendidikan responden yang berpendidikan tinggi (perguruan tinggi) sebanyak 71 responden $(28.4 \%)$ dan pendidikan rendah (SD/SMP/SMA) sebanyak 179 responden (71.6\%). Selama penelitian berlangsung pendidikan tinggi lebih mudah menyerap pertanyaan yang diberikan saat wawancara dibandingkan yang berpendidikan rendah. Hubungan tingkat pendidikan dengan pengobatan sendiri untuk obat analgesik menunjukan adanya hubungan yang signifikan, yaitu dengan menggunakan metode chi square dari hasil analisis diperoleh responden dengan pendidikan rendah mempunyai peluang 0,321 kali melakukan pengobatan sendiri. 


\section{Gambaran responden berdasarkan status pekerjaan}

Tabel 5. Distribusi responden berdasarkan Status Pekerjaan di RW 09 dan RW 10 Kelurahan Sukmajaya Depok

\begin{tabular}{clcc}
\hline No & \multicolumn{1}{c}{ Pekerjaan } & Jumlah & $\%$ \\
\hline 1. & Bekerja & 190 & 76 \\
2. & Tidak Bekerja & 60 & 24 \\
\hline & Jumlah & 250 & 100 \\
\hline
\end{tabular}

Dari tabel 5 diatas dapat penghasilan dibawah UMR yaitu diketahui bahwa sebanyak 190 sebanyak 122 responden $(48.8 \%)$ responden $(76 \%)$ bekerja, dan sebanyak dengan responden yang berpenghasilan 60 responden (24\%) tidak bekerja. Dari diatas UMR yaitu sebanyak 128 hasil penelitian status responden responden $(51.2 \%)$. sebagian besar bekerja yaitu sebanyak 190 responden (76\%), tingkat penghasilan tidak ada perbedaan yang bermakna, terlihat dari tingkat

\section{B. Gambaran masyarakat tentang pengobatan sendiri (swamedikasi)}

Tabel 6. Distribusi Responden tentang Pengetahuan Pengobatan Sendiri di RW 09 dan RW 10 Kelurahan Sukmajaya Depok

\begin{tabular}{clcc}
\hline No & Gambaran Pengetahuan & Jumlah & $\%$ \\
\hline 1 & Tinggi & 180 & 72 \\
2 & Rendah & 70 & 28 \\
\hline & Jumlah & 250 & 100 \\
\hline
\end{tabular}

Dari tabel 6 dapat diketahui bahwa sebanyak 180 responden $(72 \%)$ memiliki pengetahuan tentang pengobatan sendiri tinggi, dan sebanyak 70 responden (28\%) pengetahuan tentang pengobatan sendiri rendah. Dari hasil penelitian, masyarakat di RW 09 dan RW 10 Kelurahan Sukmajaya Depok yang melakukan pengobatan sendiri yaitu sebanyak 225 responden (90\%). Sebagian besar responden ternyata melakukan pengobatan sendiri untuk meredakan nyeri.
Dari hasil penelitian dapat dilihat bahwa pengetahuan responden tentang swamedikasi cukup tinggi yaitu sebanyak 180 responden (72\%). Demikian juga pengetahuan responden terhadap analgesik yaitu sebanyak 147 responden $(58.8 \%)$.

Hubungan pengetahuan swamedikasi responden dengan pengobatan sendiri terbukti adanya hubungan yang signifikan, yaitu dengan metode chi square, dari hasil analisis diperoleh responden dengan pengetahuan swamedikasi yang tinggi 
mempunyai peluang 3,193 kali untuk melakukan pengobatan sendiri.

\section{Hubungan umur dengan pengobatan sendiri obat analgesik}

Tabel 7. Distribusi Responden berdasarkan Umur dengan Pengobatan Sendiri obat analgesik di RW 09 dan RW 10 Kelurahan Sukmajaya Depok

\begin{tabular}{lcccccc}
\hline \multirow{1}{*}{ Umur } & \multicolumn{9}{c}{ Anamedikasi Obat } & & \\
& \multicolumn{2}{c}{ Tidak } & \multicolumn{2}{c}{ Ya } & P Value & OR (95\%CI) \\
& $\mathrm{N}$ & $\%$ & $\mathrm{~N}$ & $\%$ & & \\
\cline { 1 - 1 } <30 tahun & 10 & 10.1 & 89 & 89.9 & & 1.019 \\
$\geq 30$ tahun & 15 & 9.9 & 136 & 90.1 & 1.000 & $0.438-2.368$ \\
Total & 25 & 10 & 225 & 90 & & \\
\hline
\end{tabular}

Dari tabel 7 dapat diketahui bahwa responden umur <30 tahun yang melakukan pengobatan sendiri sebesar $89.9 \%$ sedangkan responden umur $\geq 30$ tahun yang melakukan pengobatan sendiri sebesar $90.1 \%$. Hasil uji statistik diperoleh nilai $\mathrm{p}$ value $>0.05$ sehingga secara statistik tidak terbukti adanya hubungan yang signifikan antara umur dengan pengobatan sendiri pada obat analgesik di Kelurahan Sukmajaya Depok.

\section{Hubungan tingkat pendidikan dengan pengobatan sendiri obat analgesik}

Tabel 8. Distribusi Responden berdasarkan tingkat Pendidikan dengan Pengobatan Sendiri Obat Analgesik di RW 09 dan RW 10 Kelurahan Sukmajaya Depok

\begin{tabular}{|c|c|c|c|c|c|c|}
\hline \multirow{4}{*}{ Pendidikan } & \multicolumn{4}{|c|}{ Swamedikasi Obat } & \multirow{4}{*}{$\begin{array}{c}\mathrm{P} \\
\text { Value }\end{array}$} & \multirow{4}{*}{ OR $(95 \% \mathrm{CI})$} \\
\hline & & Anal & & & & \\
\hline & \multicolumn{2}{|c|}{ Tidak } & \multicolumn{2}{|c|}{$\mathrm{Ya}$} & & \\
\hline & $\mathrm{N}$ & $\%$ & $\mathrm{~N}$ & $\%$ & & \\
\hline Rendah & 12 & 6.7 & 167 & 93.3 & & 0.321 \\
\hline Tinggi & 13 & 18.3 & 58 & 81.7 & 0.012 & \\
\hline Total & 25 & 10 & 225 & 90 & & $0.150-0.142$ \\
\hline
\end{tabular}

Dari tabel 8 dapat diketahui bahwa responden dengan pendidikan rendah yang melakukan pengobatan sendiri pada obat analgesik sebesar
93.3\% sedangkan responden dengan pendidikan tinggi yang melakukan pengobatan sendiri pada obat analgesik sebesar $81.7 \%$. hasil uji statistik diperoleh nilai $\mathrm{p}$ value $<0.05$ sehingga 
secara statistik terbukti adanya hubungan yang signifikan antara pendidikan dengan pengobatan sendiri pada obat analgesik di Kelurahan Sukmajaya Depok. Dari hasil analisis diperoleh nilai $\mathrm{OR}=0,321$ artinya responden dengan pendidikan yang rendah mempunyai peluang 0,321 kali melakukan pengobatan sendiri pada obat analgesik dibanding dengan tingkat pendidikan yang tinggi.

\section{Hubungan status pekerjaan dengan pengobatan sendiri obat analgesik}

Tabel 9. Distribusi Responden berdasarkan Status Pekerjaan dengan Pengobatan Sendiri Obat Analgesik di RW 09 dan RW 10 Kelurahan Sukmajaya Depok

\begin{tabular}{|c|c|c|c|c|c|c|}
\hline \multirow{3}{*}{ Pekerjaan } & \multicolumn{4}{|c|}{$\begin{array}{c}\text { Swamedikasi Obat } \\
\text { analgesik }\end{array}$} & \multirow{3}{*}{$\begin{array}{c}\mathrm{P} \\
\text { Value }\end{array}$} & \multirow{3}{*}{ OR $(95 \% \mathrm{CI})$} \\
\hline & \multicolumn{2}{|c|}{ Tidak } & \multicolumn{2}{|c|}{$\mathrm{Ya}$} & & \\
\hline & $\mathrm{n}$ & $\%$ & $\mathrm{~N}$ & $\%$ & & \\
\hline Bekerja & 19 & 10 & 171 & 90 & & 1.000 \\
\hline Tidak bekerja & 6 & 10 & 54 & 90 & 1.000 & $0380 ? 631$ \\
\hline Total & 25 & 10 & 225 & 90 & & $0.380-2.631$ \\
\hline
\end{tabular}

Dari tabel 9 dapat diketahui bahwa responden yang bekerja melakukan pengobatan sendiri sebesar $90 \%$ sedangkan responden yang tidak bekerja melakukan

Tabel 10. Distribusi Responden berdasarkan Tingkat Penghasilan dengan Pengobatan Sendiri Obat Analgesik di RW 09 dan RW 10 Kelurahan Sukmajaya Depok

\begin{tabular}{|c|c|c|c|c|c|c|}
\hline \multirow{4}{*}{ Penghasilan } & \multicolumn{4}{|c|}{ Swamedikasi Obat } & \multirow{4}{*}{$\begin{array}{c}\mathrm{P} \\
\text { Value }\end{array}$} & \multirow{4}{*}{ OR $(95 \% \mathrm{CI})$} \\
\hline & & & gesik & & & \\
\hline & \multicolumn{2}{|c|}{ Tidak } & \multicolumn{2}{|c|}{$\mathrm{Ya}$} & & \\
\hline & $\mathrm{N}$ & $\%$ & $\mathrm{n}$ & $\%$ & & \\
\hline$<2.700 .000$ & 10 & 8.2 & 112 & 91.8 & \multirow{3}{*}{0.473} & 0.673 \\
\hline$\geq 2.700 .000$ & 15 & 11.7 & 113 & 88.3 & & \multirow{2}{*}{$0.290-1.561$} \\
\hline Total & 25 & 10 & 225 & 90 & & \\
\hline
\end{tabular}

Dari tabel 10 dapat diketahui bahwa responden berpenghasilan tinggi melakukan pengobatan sendiri sebesar 91.8\% sedangkan responden yang berpenghasilan rendah melakukan pengobatan sendiri sebesar $88.3 \%$. Hasil uji statistik diperoleh nilai $\mathrm{p}$ value $>0.05$ sehingga secara statistik tidak terbukti adanya hubungan yang signifikan antara tingkat pendidikan dengan pengobatan 
sendiri pada obat analgesik di Kelurahan Sukmajaya Depok.
4. Hubungan pengetahuan swamedikasi dengan pengobatan sendiri obat analgesic

Tabel 11. Distribusi Responden berdasarkan Pengetahuan Swamedikasi dengan Pengobatan Sendiri Obat Analgesik di RW 09 dan RW 10 Kelurahan Sukmajaya Depok

\begin{tabular}{|c|c|c|c|c|c|c|}
\hline \multirow{4}{*}{$\begin{array}{l}\text { Pengetahuan } \\
\text { Swamedikasi }\end{array}$} & \multicolumn{4}{|c|}{ Swamedikasi Obat } & \multirow{4}{*}{ P Value } & \multirow{4}{*}{ OR $(95 \% \mathrm{CI})$} \\
\hline & \multicolumn{4}{|c|}{ Analgesik } & & \\
\hline & \multicolumn{2}{|c|}{ Tidak } & \multicolumn{2}{|c|}{$\mathrm{Ya}$} & & \\
\hline & $\mathrm{N}$ & $\%$ & $\mathrm{~N}$ & $\%$ & & \\
\hline Rendah & 13 & 18.6 & 57 & 81.4 & \multirow{3}{*}{0.010} & 3.193 \\
\hline Tinggi & 12 & 6.7 & 168 & 93.3 & & \multirow{2}{*}{$1.378-7.397$} \\
\hline Total & 25 & 10 & 225 & 90 & & \\
\hline
\end{tabular}

Dari tabel 11 dapat diketahui bahwa responden yang berpengetahuan rendah melakukan pengobatan sendiri sebesar $81.4 \%$ sedangkan responden yang berpengetahuan tinggi melakukan pengobatan sendiri sebesar $93.3 \%$. hasil uji statistik diperoleh nilai $\mathrm{p}$ value $<0.05$ sehingga secara statistik terbukti adanya hubungan yang signifikan antara pengetahuan swamedikasi dengan pengobatan sendiri pada obat analgesik di Kelurahan Sukmajaya Depok. Dari hasil analisis diperoleh nilai $\mathrm{OR}=3,193$ artinya responden dengan pengetahuan swamedikasi yang tinggi mempunyai peluang 3,193 kali melakukan pengobatan sendiri pada obat analgesik dibanding dengan pengetahuan swamedikasi yang rendah.

\section{Hubungan pengetahuan analgesik dengan pengobatan sendiri obat analgesik}

\begin{tabular}{|c|c|c|c|c|c|}
\hline \multirow{4}{*}{$\begin{array}{c}\text { Pengetahuan } \\
\text { Analgesik }\end{array}$} & \multicolumn{4}{|c|}{ Swamedikasi Obat } & \multirow{3}{*}{ OR $(95 \% \mathrm{CI})$} \\
\hline & \multicolumn{3}{|c|}{ Analgesik } & & \\
\hline & \multicolumn{2}{|c|}{ Tidak } & $\mathrm{Ya}$ & \multirow{2}{*}{$\mathrm{P}$ Value } & \\
\hline & $\mathrm{N}$ & $\%$ & $\mathrm{~N}$ & & \\
\hline Rendah & 12 & 11.7 & 91 & \multirow[b]{2}{*}{0.607} & 1.359 \\
\hline Tinggi & 13 & 8.8 & 134 & & \multirow{2}{*}{$594-3.113$} \\
\hline Total & 25 & 10 & 225 & 90 & \\
\hline $\begin{array}{l}\text { Dari tabel } 1 \\
\text { responden den } \\
\text { ik yang ren } \\
\text { atan sendiri pad } \\
88.3 \% \text { sedan }\end{array}$ & $\begin{array}{l}\text { dapa } \\
n \text { pe }\end{array}$ & $\begin{array}{l}\text { liketa } \\
\text { setahy } \\
\text { lakuk }\end{array}$ & & $\begin{array}{l}\text { dengan peng } \\
\text { tinggi melak } \\
\text { pada obat a } \\
\text { Hasil uji statis } \\
>0.05 \text { sehing } \\
\text { terbukti ad. }\end{array}$ & $\begin{array}{l}\text { thuan analgesik yang } \\
\text { an pengobatan sendiri } \\
\text { lgesik sebesar } 91.2 \% \\
\text { diperoleh nilai p value } \\
\text { secara statistik tidak } \\
\text { ya hubungan yang }\end{array}$ \\
\hline
\end{tabular}


signifikan antara pengetahuan analgesik dengan pengobatan sendiri pada obat analgesik di Kelurahan Sukmajaya Depok.

\section{SIMPULAN}

Berdasarkan penelitian yang sudah dilakukan maka dapat diambil kesimpulan sebagai berikut:

1. Dari 250 Responden, 225 responden (90\%) pernah melakukan swamedikasi dengan obat analgesik, dan $72 \%$ memiliki pengetahuan swamedikasi cukup tinggi serta $58,8 \%$ memiliki pengetahuan tentang obat analgesiknya.

2. Responden dengan pendidikan rendah mempunyai peluang 0,321 kali melakukan pengobatan sendiri, sedangkan responden yang memiliki pengetahuan swamedikasi cukup tinggi mempunyai peluang 3,193 kali melakukan pengobatan sendiri, dan alasan responden melakukan swamedikasi yaitu penyakit dianggap masih ringan.

\section{UCAPAN TERIMAKASIH}

Terimakasih kepada Akademi Farmasi Bhumi Husada Jakarta yang telah mendanai penelitian ini.

\section{DAFTAR PUSTAKA}

Asmarani, E., 2014, Gambaran Pengetahuan dan Kerasionalan Penggunaan Obat Bebas dan Bebas Terbatas pada Swamedikasi oleh Masyarakat di RW 015 Kelurahan Mampang Kecamatan Pancoran Mas Depok Tahun 2014. Karya Tulis Ilmiah. Jurusan Farmasi Poltekes II, Jakarta

Departemen Kesehatan RI. 2000. Ditjen Bina Kefarmasian dan Alat Kesehatan. Pedoman Penggunaan Obat Bebas dan Bebas Terbatas, Jakarta.

Supardi, S., Notosiswoyo, 2006, M. Pengobatan Sendiri Sakit Kepala Demam, Batuk, dan Flu pada Masyarakat di Desa Ciwalen, Kecamatan Warungkondang, Kabupaten Cianjur, Jawa Barat.2005. from http:// jurnal.farmasi.ui.ac.id/pdf/2005/vo2n03.

Djunarko, I., dan Hendrawati, D. 2011. Swamedikasi yang Baik dan Benar Citra Aji Pratama. Yogyakarta.

Hermawati, D.,2012. Pengaruh Edukasi Terhadap Tingkat Pengetahuan Dan Rasionalitas Penggunaan Obat Swamedikasi Pengunjung di Dua Apotek Kecamatan Cimanggis, Depok, Skripsi, Fakultas Matematika dan ilmu Pengetahuan Alam, Depok. 